Original article

\title{
Impact of flood deposits on earthworm communities in alder forests from a subalpine floodplain (Kandersteg, Switzerland)
}

\author{
Géraldine Bullinger-Weber ${ }^{\mathrm{a}, *}$, Claire Guenat ${ }^{\mathrm{b}}$, Clémence Salomé ${ }^{\mathrm{c}}$, \\ Jean-Michel Gobat ${ }^{c}$, Renée-Claire Le Bayon ${ }^{c}$ \\ a Laboratory Biogeosciences, Institute of Geology and Palaeontology, University of Lausanne, UNIL Dorigny, Bâtiment Anthropole, 1015 Lausanne, Switzerland \\ ${ }^{\mathrm{b}}$ Laboratory ECOS E WSL, Station 2, École Polytechnique Fédérale de Lausanne (EPFL), School of Architecture, Civil and Environmental Engineering (ENAC), \\ 1015 Lausanne, Switzerland \\ ${ }^{c}$ Laboratory Soil E Vegetation, Institute of Biology, University of Neuchâtel, Emile-Argand 11, 2000 Neuchâtel, Switzerland
}

\section{A R T I C L E I N F O}

\section{Article history:}

Received 31 January 2011

Received in revised form

21 June 2011

Accepted 4 August 2011

Available online $\mathrm{xxx}$

Handling editor: Christoph Tebbe

\section{Keywords:}

Floodplain

Earthworms

Bioindication

Soil

Alder forest

Subalpine level

\begin{abstract}
A B S T R A C T
In many ecosystems, bioindication is a tool to estimate biodiversity and quality of environment. In soils, invertebrates are generally suitable bioindicators, especially earthworms. In floodplains, young alluvial soils are exposed to sedimentation and erosion, and little is known about soil bioindication. Moreover, a reference state is now needed to evaluate river restoration projects. The aim of our study was thus to establish an "undisturbed" floodplain reference at the subalpine level based on earthworm communities and to test if they are indicators of fluvial dynamics. Seven plots were chosen along a stretch of the Kander River (BE, Switzerland). At each plot, a soil profile was described (carbonated Fluvisols) and topsoil was analysed. Earthworms were extracted in each plot using standard mustard extraction $\left(3 \times 1 \mathrm{~m}^{2}\right)$ and "hand sorting" method $(20 \times 20 \times 20 \mathrm{~cm})$. Eight species were identified, and Lumbricus meliboeus was found for the first time in a carbonated environment. The absence of anecics was considered, at the subalpine level, as a bioindication of the fluvial dynamics (erosion and sedimentation processes). Biomass of epigeics was positively correlated to topsoil texture and organic matter quality, and thus epigeics, sensitive to variations of topsoil composition, are bioindicators of the latest flood event at the subalpine level.
\end{abstract}

(c) 2011 Published by Elsevier Masson SAS.

\section{Introduction}

The concept of bioindicators probably first became widely used following the definition of Clements in 1920 who identified plant species as community indicators within his overall concept of plant community succession [1]. According to Markert et al. [2], a bioindicator is a living organism, even so a part of an organism or a community of organisms, which contains information on the quality of the environment. Bioindication is thus one of the organism properties, collected in the field, and giving ecological information that is used to make inferences about the quality of the environment. Such bioindication commonly refers to bioindicators which are related, directly or indirectly, to some or a complex of factors used as a barometer indicating air pressure [3]. The notion of bioindication in soils has been recently developed with the challenge of applying the expertise of soil knowledge in the

\footnotetext{
* Corresponding author. Tel.: +41 2169243 06; fax: +41 216924305

E-mail address: geraldine.bullinger@unil.ch (G. Bullinger-Weber).
}

assessment of contaminated soils and problems of soil degradation [4]. Therefore, bioindication has been applied mainly as a tool to estimate soil biodiversity and quality, such as the evaluation of pesticides impact or success of restoration methods (i.e. postmining restoration [5]). Despite the fact that bioindicators for soils are still insufficiently developed, soil invertebrates were recently considered as appropriate tools in indicating the degree to which soil may be affected by human activities [5]. For instance, mesofauna groups such as Collembola and Acarina were used to evaluate the suitability of forest soils [3] as well as environmental impacts of pollutants [6]. Oligochaeta (earthworms and enchytreids) are also generally regarded as highly suitable bioindicators, because: 1) they contain key species for ecosystem functioning, 2) they are widespread and abundant and 3) they may be used at various levels of biological organisation, ranging from molecular to ecosystem levels [7]. Focusing on these organisation levels, population growth, biomass and abundance of Oligochaeta may vary according to toxicant stress [8]. At the community and ecosystem levels, Schouten et al. [9] also demonstrated that diversity and abundance of Oligochaeta were clearly discriminative between soil 
types and land-use intensities in grasslands and horticultural farms. In addition, annelid communities may also help in characterizing soil quality [7]. Earthworms, usually considered as major ecosystem engineers [10-12], may be particularly efficient for the purpose of soil bioindication because they actively contribute to organic matter recycling and soil structuring processes [13,14]. Conversely, distribution of earthworm communities is clearly influenced by soil parameters such as soil texture combined with vegetation types, soil nutrients and $\mathrm{pH}$ values [15-17].

Very few studies have been conducted on earthworm communities in floodplains; most of those were descriptive and focused on meadows and grasslands at very low altitude (ranging from 5 to $50 \mathrm{~m}$ a.s.l.), and generally on stabilized terraces [18-20]. To our best knowledge, only three studies were conducted on earthworm communities in near-natural floodplains at mountain and subalpine levels [21-23]. Moreover, in the framework of ecosystem rehabilitation, floodplain management is now questioned and river restoration projects have thus considerably increased worldwide in recent decades $[24,25]$. To evaluate the success of floodplain restoration, a reference state to be reached by river restoration has to be determined [26] and a value assessment could be established by using reliable indicators of restoration evaluation. The most frequently used indicators to evaluate the success of river restoration aiming to increase biodiversity are based on vegetation and aquatic fauna [27]. So far, little is known about earthworms as bioindicators of restoration success. Plum and Filser [28] demonstrated in their study carried out in Northern Germany that earthworm abundance and biomass are usually reduced by extensive flooding. Indeed, floods have a large impact on alluvial soil chemistry (especially organic matter content and quality), physics (especially texture, soil thickness) and soil stabilisation (time elapsed between flood events) through sedimentation/erosion processes and organic matter fluxes. Alluvial soils are considered as young soils resulting from the interaction between in situ evolution and inheritance of both organic and mineral materials [21-23]. As a consequence, a better understanding of earthworm communities as bioindicators of environment quality may therefore be helpful to evaluate the success of restoration projects in recreating the fluvial dynamics.

The aim of our study is to establish an "undisturbed" floodplain reference at the subalpine level based on earthworm communities (diversity, ecological categories, abundance and biomass). The specific objective of this study is to test if earthworm communities may be used in an undisturbed subalpine floodplain as bioindicators of the fluvial dynamics. Thus, we hypothesize that earthworm communities are bioindicators of the fluvial dynamics reflected by the physical soil parameters (especially texture) and the organic matter (quantity and quality) of the topsoil layer. In a similar environment, i.e. same mesoclimate, same vegetation cover reflecting colonisation time (alder shrubs and trees), same organic input through in situ litter fall, same young soils regularly flooded (Fluvisols [29]) and same parental material (carbonated alluvial deposits), the topsoil layer parameters (texture, structure, thickness, organic matter content) are mostly determined by the latest flood that has led to the inheritance of mineral and organic deposits.

\section{Methods}

\subsection{Site descriptions}

The study was carried out in a Swiss subalpine floodplain site at an altitude of $1320 \mathrm{~m}$ a.s.l. along the Kander River (Canton of Bern) included in the alluvial zones inventory of national importance (162 ha [30]). This site originates mainly from calcareous deposits and exhibits natural hydrological dynamics where depositions and erosion processes still occur. General characteristics of this site are given in Table 1. The fluvial regime is pluvio-nival (floods in spring and summer due to rain and snow melt) and the mesoclimate is subalpine (high variation in air temperature between summer and winter).

Regarding earthworm and soil samplings, seven plots within the site of national importance were chosen along a $5 \mathrm{~km}$ stretch of the Kander River (Kander 1 to Kander 7 from upstream to downstream, ranging from an altitude of 1400 to $1360 \mathrm{~m}$ ) within the same vegetation unit, forests of alder shrubs and trees, representing the dominant vegetation stage in absence of mature forests. The minimal distance between plots is $300 \mathrm{~m}$ and, except during floods, plots are not far from more than $20 \mathrm{~m}$ from the riverside. All soils correspond to the Fluvisol type according to the classification of IUSS Working Group WRB [29] and are regularly flooded at least annually. In addition, all plots have been subjected to a major flood (Q20) one year before sampling date leading to erosion or deposition of some organic and mineral materials. No data about water table-level are available for this floodplain.

\subsection{Earthworm sampling}

Earthworms were collected using the standard mustard extraction [31] in three replicates of $1 \mathrm{~m}^{2}$ with a corresponding depth of about $20 \mathrm{~cm}$. The "hand sorting" method $(20 \times 20 \times 20 \mathrm{~cm})$ was done to guarantee that no earthworm remained in the soil. Earthworms were directly stored in formaldehyde $4 \%(\mathrm{v} / \mathrm{v})$ and identified in the laboratory at the species level [32,33], and classified according to the three main ecological categories (epigeics, endogeics and anecics [34]). Dead fixed adults and sub-adults were individually counted and weighed without gut clearing, and unidentified juveniles were allocated to species by assuming that the species ratios for adults and for juveniles were identical.

\subsection{Soil sampling and analyses}

In each plot, the topsoil layer, corresponding to the organomineral horizon, was collected according to the horizon thickness and analysed in the laboratory. Organic carbon (calculated by deducting the carbonates from the total carbon), total nitrogen

\section{Table 1}

General characteristics of the studied subalpine floodplain. Channel pattern type (according to Petts and Amoros [45]); flow $\left(\mathrm{m}^{3} \mathrm{~s}^{-1}\right)$; temperature $\left({ }^{\circ} \mathrm{C}\right)$ and precipitations $(\mathrm{mm})$ calculated over a period of minimum 30 years (source: MétéoSuisse FOMC, 2010, Adelboden meteorological station; http://www.meteosuisse.admin.ch/ web/fr/services/portail_des_donnees.html); flood events equivalents to a return period of at least 20 years (Q20; source: FOEN 2010, Kander-Hondrich station; http://www.hydrodaten.admin.ch/f/2469.htm), vegetation type (according to Gallandat et al. [31]).

\begin{tabular}{ll}
\hline Site characteristics & Kander River $(\mathrm{BE})$ \\
\hline Location & $46^{\circ} 28^{\prime} 01 \mathrm{~N}, 7^{\circ} 39^{\prime} 47 \mathrm{E}$ \\
Surface area (ha) & 161.6 \\
Channel pattern type & Braided river \\
Annual mean flow $\left(\mathrm{m}^{3} \mathrm{~s}^{-1}\right)$ & 2.1 \\
Max flow $\left(\mathrm{m}^{3} \mathrm{~s}^{-1}\right)\left(\mathrm{year}^{3}\right)$ & $21(2005)$ \\
Annual min flow $\left(\mathrm{m}^{3} \mathrm{~s}^{-1}\right)$ & $0.02($ winter $)$ \\
Annual mean temperature & $T=5.4$ \\
$\quad\left(1959-2009 ; T\right.$ in $\left.{ }^{\circ} \mathrm{C}\right)$ & $T=14$ (July) \\
Annual max $T\left(1959-2009 ; T\right.$ in $\left.{ }^{\circ} \mathrm{C}\right)$ & $T=-2$ (January) \\
Annual min $T\left(1959-2009 ; T\right.$ in $\left.{ }^{\circ} \mathrm{C}\right)$ & $P=1180$ \\
Mean annual precipitations & \\
$\quad(P$ in mm) & 2005 \\
Flood events $(\mathrm{Q} 20$ and more $)$ &
\end{tabular}

from 2000 to 2010

Vegetation type (main species and/or Alnus incana forests vegetation associations)
Alnus incana forests
(Calamagrostio-Alnetum incanae) 
(both measured with Carlo Erba CHN analyser), total and active $\mathrm{CaCO}_{3}$ (modified Drouineau and Galet method; n ${ }^{\circ}$ AFNOR X31105), as well as particle size distribution (modified Robinson pipette method) were determined [35].

\subsection{Statistical analysis}

All statistical analyses were performed with $\mathrm{R} 2.10 .0$ [36]. Firstly, an analysis of variance (ANOVA with Tukey HSD test) was used to test differences between earthworm data of the seven plots. A Principal Component Analysis (PCA) was used to obtain a general view of earthworm parameters and soil characteristics. Multiple regressions were used to test the influence of soil parameters on earthworm communities (using total biomass and abundance, biomass and abundance per ecological category and per species). In addition, Redundancy Analyses (RDA) were made using earthworm matrix (with biomass, abundance, total number of species, total number of adults, Shannon index data) and explained by the soil matrix. Finally, to identify which variables are predominant in the distribution of earthworm communities, forward selection of explanatory variables on the earthworm species matrix (with biomass data) were made [37].

\section{Results}

\subsection{Soil parameters}

All soils described were carbonated and classified as Fluvisols [29]. They developed in alluvial deposits and were mainly sandy with a good drainage. Some hydromorphic features were observed, but only in the lower part of the profile (Kander 5 and 7). They differed mainly by their topsoils, especially thickness and physicochemical characteristics of the organo-mineral horizon (Table 2). The PCA analysis (Fig. 1) illustrated that the first principal component axis PC1 (explaining $69 \%$ of the total variance) separated the samples according to the particle size (silt content on the left of the graph related to Kander 7, downstream of the studied stretch, and sand content on the right side related to Kander 2, 5 and 6), the amount of active carbonates (on the left side related to Kander 7 and also Kander 4) and the $\mathrm{C} / \mathrm{N}$ ratio in a lesser extend (on the right side of PC1). The second axis PC2 (explaining $16.3 \%$ of the total variance) discriminated the organic carbon content with Kander 1 on the top, and Kander 2 at the bottom that contains the lowest amount.

\subsection{Earthworm communities}

Eight species of earthworms were identified (Lumbricus rubellus, Lumbricus meliboeus, Dendrobaena octaedra, Dendrodrilus rubidus, Octolasion tyrtaeum lacteum, O. t. tyrtaeum, Allolobophora rosea,

Table 2

Soil characteristics of the seven plots: sand content (\%), silt content (\%), organic carbon (\%), $\mathrm{C} / \mathrm{N}$ ratio, active $\mathrm{CaCO}_{3}(\%)$, total $\mathrm{CaCO}_{3}(\%)$. To minimize the number of factors, clay content is not shown in this table.

\begin{tabular}{llllllll}
\hline Plots & $\begin{array}{l}\text { Horizon } \\
\text { depth } \\
(\mathrm{cm})\end{array}$ & $\begin{array}{l}\text { Sand } \\
(\%)\end{array}$ & $\begin{array}{l}\text { Silt } \\
(\%)\end{array}$ & $\begin{array}{l}\text { Organic } \\
\text { carbon } \\
(\%)\end{array}$ & $\begin{array}{l}\mathrm{C} / \mathrm{N} \\
\begin{array}{l}\text { Active } \\
\mathrm{CaCO}_{3} \\
(\%)\end{array}\end{array}$ & $\begin{array}{l}\text { Total } \\
\mathrm{CaCO}_{3} \\
(\%)\end{array}$ \\
\hline Kander 1 & $0-10$ & 61 & 30 & 17.01 & 19 & 4.76 & 41 \\
Kander 2 & $0-8$ & 80 & 20 & 1.61 & 13 & 4.96 & 41 \\
Kander 3 & $0-4$ & 64 & 28 & 6.74 & 20 & 6.17 & 25 \\
Kander 4 & $0-10$ & 48 & 46 & 5.43 & 16 & 7.78 & 29 \\
Kander 5 & $0-6$ & 87 & 13 & 2.48 & 41 & 2.21 & 36 \\
Kander 6 & $0-10$ & 86 & 14 & 1.13 & 23 & 2.41 & 28 \\
Kander 7 & $0-2$ & 30 & 58 & 7.91 & 19 & 12.63 & 39 \\
\hline
\end{tabular}

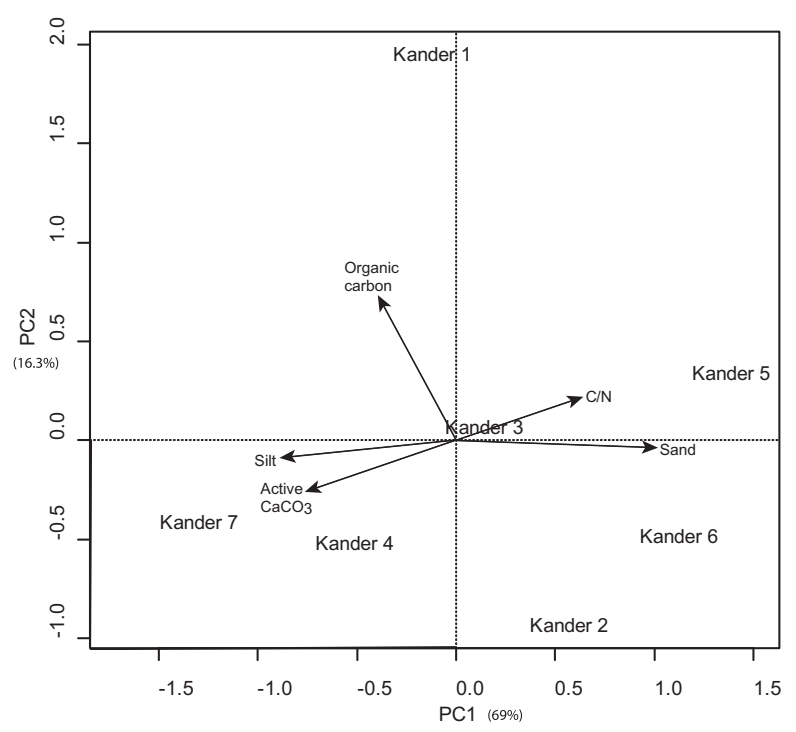

Fig. 1. PCA analysis of soil parameters for each plot: sand content (\%), silt content (\%), organic carbon content (\%), C/N ratio, active calcium carbonates (\%).

Nicodrilus caliginosus caliginosus) of which none were anecic (Table 3). The plot Kander 1 showed the lowest number of species (two epigeics), whereas Kander 7 the highest (three epigeics and four endogeics). Significant differences in total biomass and abundance between plots were observed (Fig. 2); Kander 7 showed the highest values $\left(32.09 \mathrm{~g} \mathrm{~m}^{-2}\right.$ and 53 ind $\mathrm{m}^{-2}$ ) and Kander 1 the lowest $\left(0.60 \mathrm{~g} \mathrm{~m}^{-2}\right.$ and 3 ind $\left.\mathrm{m}^{-2}\right)$. Kander 2 and 3 were quite similar regarding biomass and abundance (between 13.55 and $15.37 \mathrm{~g} \mathrm{~m}^{-2}$, and 53 and 51 ind $\mathrm{m}^{-2}$ ), but the abundance values were variable (high standard deviations). There was no significant difference of these two plots with Kander 7.

Many earthworm parameters varied among plots (Table 4). No endogeic species was found in Kander 1 and 6, and a large proportion of epigeics was observed in Kander 2 and 3. Kander 4 and 5 presented a high proportion of biomass of epigeics, but a much lower proportion of abundance. On the contrary, Kander 7 showed the largest proportion of endogeic earthworms, as well as the highest Shannon index (1.386). A projection of these data using a PCA analysis confirmed these results (Fig. 3). The first principal component axis PC1 (explaining $57.6 \%$ of the total variance) showed that Kander 7 was clearly different from the other plots in terms of endogeics' biomass and abundance, number of adults and Shannon index value. The second axis PC2 (explaining 26.9\% of the total variance) discriminated mainly Kander 2 and 3 (on the bottom of the graph), which had a high abundance and biomass of epigeics.

\subsection{Earthworms as bioindicators of environment quality}

The total biomass of epigeics was influenced by all soil parameters, whereas active carbonates content had an influence on the total abundance of epigeics (Table 5). Moreover, the epigeics' proportion was correlated to the $\mathrm{C} / \mathrm{N}$ ratio. Silts and active carbonates had a significant effect on the biomass of $L$. rubellus and A. rosea and this latter species was the only one influenced by total organic carbon.

The results of RDA analysis (Fig. 4A) showed a shift between plots with endogeic species (on the right side of the RDA1 axis explaining $57 \%$ of the total variance) or without endogeics (on the left side of the graph). Earthworm communities were related to habitats mainly characterized by: i) sand content (Kander 6), ii) active carbonates amount, which was correlated to silt content 
Table 3

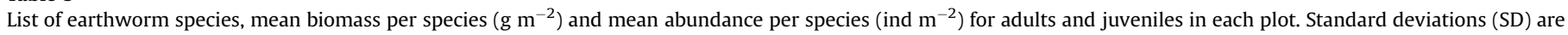
shown.

\begin{tabular}{|c|c|c|c|c|c|c|c|c|}
\hline Plots & Earthworm species & & $\begin{array}{l}\text { Adult biomass } \\
\left(\mathrm{g} \mathrm{m}^{-2}\right)\end{array}$ & $\begin{array}{l}\text { Juvenile biomass } \\
\left(\mathrm{g} \mathrm{m}^{-2}\right)\end{array}$ & $\begin{array}{l}\text { Adult abundance } \\
\text { (ind } \mathrm{m}^{-2} \text { ) }\end{array}$ & $\begin{array}{l}\text { Juvenile abundance } \\
\text { (ind } \mathrm{m}^{-2} \text { ) }\end{array}$ & $\begin{array}{l}\text { Total biomass } \\
\left(\mathrm{g} \mathrm{m}^{-2} \pm \mathrm{SD}\right)\end{array}$ & $\begin{array}{l}\text { Total abundance } \\
\text { (ind } \mathrm{m}^{-2} \text { ) }\end{array}$ \\
\hline \multirow[t]{2}{*}{ Kander 1} & $\begin{array}{l}\text { Lumbricus rubellus } \\
\text { (Hoffmeister, 1843) }\end{array}$ & epigeic & 0.23 & 0.37 & 1 & 1 & $0.61( \pm 0.76)$ & $3( \pm 1)$ \\
\hline & $\begin{array}{l}\text { Dendrobaena octaedra } \\
\text { (Savigny, 1826) }\end{array}$ & epigeic & - & 0.01 & - & 1 & & \\
\hline \multirow[t]{5}{*}{ Kander 2} & L. rubellus & epigeic & 3.03 & 9.06 & 4 & 40 & $13.55( \pm 4.74)$ & $53( \pm 18)$ \\
\hline & L. meliboeus (Rosa, 1884) & epigeic & 0.30 & - & 1 & - & & \\
\hline & $\begin{array}{l}\text { Dendrodrilus rubidus } \\
\text { (Savigny, 1826) }\end{array}$ & epigeic & 0.09 & - & 1 & - & & \\
\hline & $\begin{array}{l}\text { Octolasion tyrtaeum lacteum } \\
\text { (Oerley, 1885) }\end{array}$ & endogeic & 0.83 & 0.22 & 1 & 5 & & \\
\hline & D. octaedra & epigeic & - & 0.02 & - & 1 & & \\
\hline \multirow[t]{5}{*}{ Kander 3} & D. rubidus & epigeic & 0.09 & 0.09 & 1 & 1 & $15.39( \pm 3.97)$ & $51( \pm 28)$ \\
\hline & L. rubellus & epigeic & 1.85 & 11.00 & 2 & 37 & & \\
\hline & L. meliboeus & epigeic & 0.52 & - & 1 & - & & \\
\hline & $\begin{array}{l}\text { Allolobophora rosea } \\
\text { (Savigny, 1826) }\end{array}$ & endogeic & 0.07 & 0.05 & 1 & 1 & & \\
\hline & O. tyrtaeum lacteum & endogeic & 1.46 & 0.26 & 2 & 5 & & \\
\hline \multirow[t]{3}{*}{ Kander 4} & L. rubellus & epigeic & 0.33 & 0.89 & 1 & 2 & $1.84( \pm 1.80)$ & $8( \pm 3)$ \\
\hline & A. rosea & endogeic & 0.33 & 0.27 & 2 & 2 & & \\
\hline & D. rubidus & epigeic & - & 0.02 & - & 1 & & \\
\hline \multirow[t]{3}{*}{ Kander 5} & D. rubidus & epigeic & 0.16 & 0.07 & 2 & 3 & $3.65( \pm 1.02)$ & $40( \pm 19)$ \\
\hline & L. rubellus & epigeic & - & 2.97 & - & 8 & & \\
\hline & $\begin{array}{l}\text { O. tyrtaeum tyrtaeum } \\
\text { (Savigny, 1826) }\end{array}$ & endogeic & 0.18 & 0.27 & 1 & 26 & & \\
\hline \multirow[t]{3}{*}{ Kander 6} & D. rubidus & epigeic & 0.16 & 0.17 & 3 & 7 & $7.14( \pm 4.11)$ & $29( \pm 21)$ \\
\hline & L. rubellus & epigeic & 1.52 & 4.86 & 2 & 16 & & \\
\hline & L. meliboeus & epigeic & 0.43 & - & 1 & - & & \\
\hline \multirow[t]{7}{*}{ Kander 7} & L. rubellus & epigeic & 5.19 & 7.54 & 6 & 23 & $32.08( \pm 6.48)$ & $53( \pm 2)$ \\
\hline & L. meliboeus & epigeic & 0.79 & - & 1 & - & & \\
\hline & O. tyrtaeum lacteum & endogeic & 3.84 & 0.69 & 4 & 2 & & \\
\hline & O. tyrtaeum tyrtaeum & endogeic & 11.97 & 0.37 & 6 & 3 & & \\
\hline & A. rosea & endogeic & 0.53 & 0.12 & 2 & 1 & & \\
\hline & $\begin{array}{l}\text { Nicodrilus cali. caliginosus } \\
\text { (Savigny, 1826) }\end{array}$ & endogeic & 0.83 & 0.16 & 3 & 1 & & \\
\hline & D. rubidus & epigeic & - & 0.05 & - & 1 & & \\
\hline
\end{tabular}
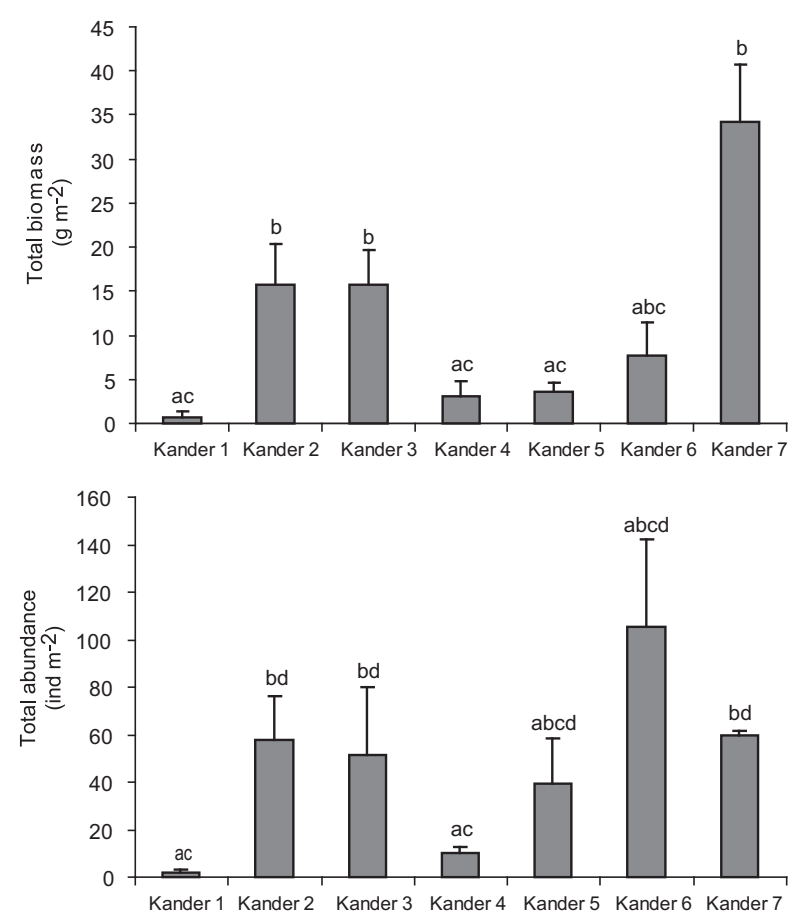

Fig. 2. Total biomass and abundance for each plot (Kander 1 to $7, \mathrm{~g} \mathrm{~m}^{-2}$ and ind $\mathrm{m}^{-2}$, calculated by the mean of each plot of $1 \mathrm{~m}^{2}$ ). Standard deviations are shown and letters above bars represent results from Tukey's HSD tests for the one way ANOVAs.
(Kander 7; axis RDA1), and iii) organic carbon content, related to a high $\mathrm{C} / \mathrm{N}$ ratio, however to a lesser extent (Kander 4 and 5; RDA2). Results of forward selection of explanatory variables showed that the best model (Fig. 4B; 2 -ways ANOVA, $F_{3,3}=3.895, p<0.01$ ) took into account the biomass of each species and explained three soil parameters (active carbonates content, silt amount and $\mathrm{C} / \mathrm{N}$ ratio). When a permutation test for RDA under reduced model (terms added sequentially - first to last) is performed, only two soil parameters are significant, respectively active carbonates (2-ways ANOVA, $\left.F_{1,3}=6.889, p<0.001\right)$, correlated to silt content, and $\mathrm{C} / \mathrm{N}$ ratio (2-ways ANOVA, $F_{1,3}=3.463, p<0.01$ ).

\section{Discussion}

Topsoil characteristics correspond to young carbonate-rich soils with a low degree of in situ soil development due to fluvial dynamics leading to a similar vegetation stage with a short time of stabilisation. As mentioned by Cierjacks et al. [38], a large variability of soil properties within one vegetation type may be observed. These authors concluded that there is no clear correlation between vegetation type and soil properties. Our results confirm other observations about the high spatial and temporal variability within plots that mainly results from texture and organic matter content, and quality in a lesser extent, and reflecting by a wide mosaic of topsoils [39]. These last authors also observed that $\mathrm{C} / \mathrm{N}$ ratios were not significantly correlated with the silt plus clay fractions in the topsoil or the sediment, but were mostly due to differences in the relative importance of external inputs and autochthonous organic matter. The importance of inheritance 
Table 4

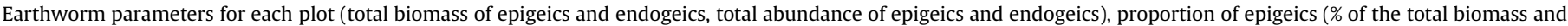
abundance), number of adults, Shannon index and number of species.

\begin{tabular}{|c|c|c|c|c|c|c|c|c|c|}
\hline Plots & $\begin{array}{l}\text { Biomass } \\
\text { epigeics } \\
\left(\mathrm{g} \mathrm{m}^{-2}\right)\end{array}$ & $\begin{array}{l}\text { Biomass } \\
\text { endogeics } \\
\left(\mathrm{g} \mathrm{m}^{-2}\right)\end{array}$ & $\begin{array}{l}\text { Abundance } \\
\text { epigeics } \\
\text { (ind } \mathrm{m}^{-2} \text { ) }\end{array}$ & $\begin{array}{l}\text { Abundance } \\
\text { endogeics } \\
\text { (ind } \mathrm{m}^{-2} \text { ) }\end{array}$ & $\begin{array}{l}\text { Epigeics } \\
\text { (\% of total } \\
\text { biomass) }\end{array}$ & $\begin{array}{l}\text { Epigeics } \\
\text { (\% of total } \\
\text { abundance) }\end{array}$ & $\begin{array}{l}\text { Number } \\
\text { of adults }\end{array}$ & $\begin{array}{l}\text { Shannon } \\
\text { index }\end{array}$ & $\begin{array}{l}\text { Number of } \\
\text { species }\end{array}$ \\
\hline Kander 1 & 0.60 & 0.00 & 2 & 0 & 100 & 100 & 6 & 0.45 & 2 \\
\hline Kander 2 & 12.50 & 1.05 & 46 & 6 & 92 & 88 & 4 & 0.534 & 5 \\
\hline Kander 3 & 13.54 & 1.84 & 42 & 9 & 88 & 83 & 4 & 0.756 & 5 \\
\hline Kander 4 & 1.24 & 0.60 & 3 & 4 & 67 & 41 & 11 & 0.819 & 3 \\
\hline Kander 5 & 3.19 & 0.46 & 13 & 27 & 87 & 33 & 2 & 0.85 & 3 \\
\hline Kander 6 & 7.14 & 0 & 28 & 0 & 100 & 100 & 2 & 0.75 & 3 \\
\hline Kander 7 & 13.58 & 19 & 30 & 22 & 40 & 56 & 14 & 1.386 & 7 \\
\hline Total & 51.79 & 22.95 & 164 & 68 & 70 & 71 & 42 & 1.26 & 8 \\
\hline
\end{tabular}

(mineral and organic) has already been highlighted in Guenat et al. [21] who demonstrated that the initial composition of the alluvial deposits may influence the topsoil characteristics, especially in initial stages of soil formation. The spatial variation of inherited material can thus be considered as an indicator of a near-natural fluvial dynamics at the subalpine level, where erosion and sedimentation are the main processes involved, and may partly determine the quality of habitat for earthworm communities.

About earthworm communities, total number and biomass in our study are low (6-158 ind $\mathrm{m}^{-2}$ and $1.8-96.3 \mathrm{~g} \mathrm{~m}^{-2}$, respectively) compared to those reported from other types of pastures (South Australia) and a flooded grassland in the Netherlands (maximum density of 523 and 1912 ind $\mathrm{m}^{-2}$ and maximum biomass of 159 and $276 \mathrm{~g} \mathrm{~m}^{-2}$ ) [40] [19]. We hypothesize that our low values may be due to the characteristics of alluvial soils, where earthworm abundance is generally lower according to Edwards and Bohlen [13]. Moreover, the maximum abundance and biomass found in this study are similar to those measured in a Swiss mountain level floodplain [22].

Eight species and subspecies, all inventoried in Switzerland, were determined in our study plots. Similar numbers of species were observed in temperate forests [41], coastal and floodplain meadows in West Estonia [20] and pastures of a chalky slope of the Seine Valley [42]. Moreover, a maximum of five species was found in pasture soils of South Australia [40] and in flooded grassland [19].

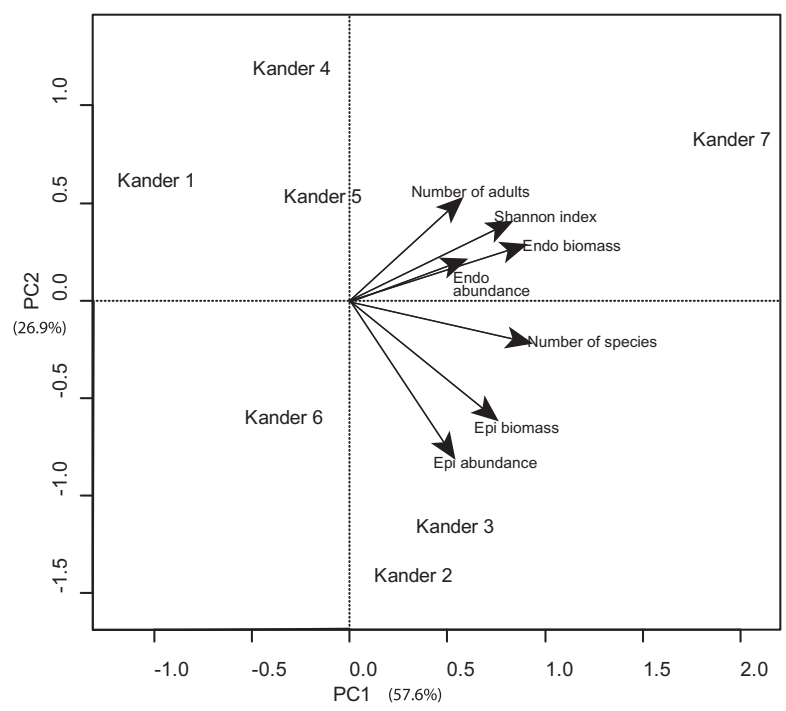

Fig. 3. PCA analysis of earthworm parameters for each plot (Kander 1-7): total biomass of epigeics (Epi biomass, $\mathrm{g} \mathrm{m}^{-2}$ ), total biomass of endogeics (Endo biomass, $\mathrm{g} \mathrm{m}^{-2}$ ), total abundance of epigeics (Epi abundance, ind $\mathrm{m}^{-2}$ ), total abundance of endogeics (Endo abundance, ind $\mathrm{m}^{-2}$ ), number of adults, Shannon index, number of species.
Despite the relatively small riparian sampling area, the total diversity of species and its variability among plots were high. All sampled species are common earthworm species. A. rosea, L. rubellus and O. t. tyrtaeum have been recorded from a wide range of habitats including banks of rivers and lakes [33]. A. rosea is usually found in soils with low organic matter content and L. rubellus prefers soils with high organic matter amount. Concerning 0 . t. lacteum, a large variation of size may be observed depending on the environment [32] and this species is mainly found in mountain habitats and humid soils with medium amount of organic matter. The earthworm L. meliboeus, considered by Bouché [32] as exclusively inhabiting mountain environments with acid soils with a medium content of organic matter, was also present in the carbonated-rich soils of our plots. Finally, N. c. caliginosus is reported in low organic matter habitats and prefers humidity. In our study, correlation with organic matter content is not clear and established for the above mentioned species.

The absence of anecic earthworms is here probably not due to the altitudinal level, but to the riparian conditions. Salomé et al. [23] observed A. caliginosa nocturna in an adjacent pasture to our site. Other parameters, mainly related to the particular conditions of subalpine floodplain, flooding and/or inter specific competition, may explain this absence of anecic species. Fründ et al. [43] reported that soil moisture is the key limiting factor for earthworm populations, and flood events are considered to sharply reduce earthworm populations. It has also been demonstrated that the impacts of flood events are different according to soil type, season and duration of flood events, and species [28]. Several earthworm species, including $L$. rubellus, may survive several weeks in flooded soils. In addition, L. rubellus is considered as an r-strategist [28], adapted to life in frequently flooded environments. In our case at the Kander River site, floods events are short and act mainly through erosion and sedimentation processes. The anoxic period is probably

\section{Table 5}

Multiple regressions on the different earthworm and soil parameter data: total biomass and abundance, biomass and abundance of epigeics, biomass and abundance of endogeics, epigeics (\% of total biomass and \% of total abundance), biomass and abundance of the eight species (L. rubellus, L. meliboeus, Dendrobaena octaedra, Dendrodrilus rubidus, Octolasion tyrtaeum lacteum, O. t. tyrtaeum, Allolobophora rosea (=A. rosea), Nicodrilus caliginosus caliginosus). Only significant relationships (significance level less than 0.05 ) are shown in table.

\begin{tabular}{llllll}
\hline & Sand & Silt & $\begin{array}{l}\text { Total } \\
\text { organic } \\
\text { carbon }\end{array}$ & $\mathrm{C} / \mathrm{N}$ & $\begin{array}{l}\text { Active } \\
\text { carbonates }\end{array}$ \\
\hline Biomass of epigeics & $0.02^{*}$ & $0.01^{* *}$ & $0.02^{*}$ & $0.02^{*}$ & $0.01^{* *}$ \\
Abundance of epigeics & - & - & - & - & $0.05^{*}$ \\
Epigeics proportion (\%) & - & - & - & $0.04^{*}$ & - \\
$\begin{array}{c}\text { Biomass per species } \\
\text { L. rubellus biomass }\end{array}$ & - & $0.03^{*}$ & - & - & $0.02^{*}$ \\
A. rosea biomass & - & - & $0.05^{*}$ & - & - \\
\hline
\end{tabular}



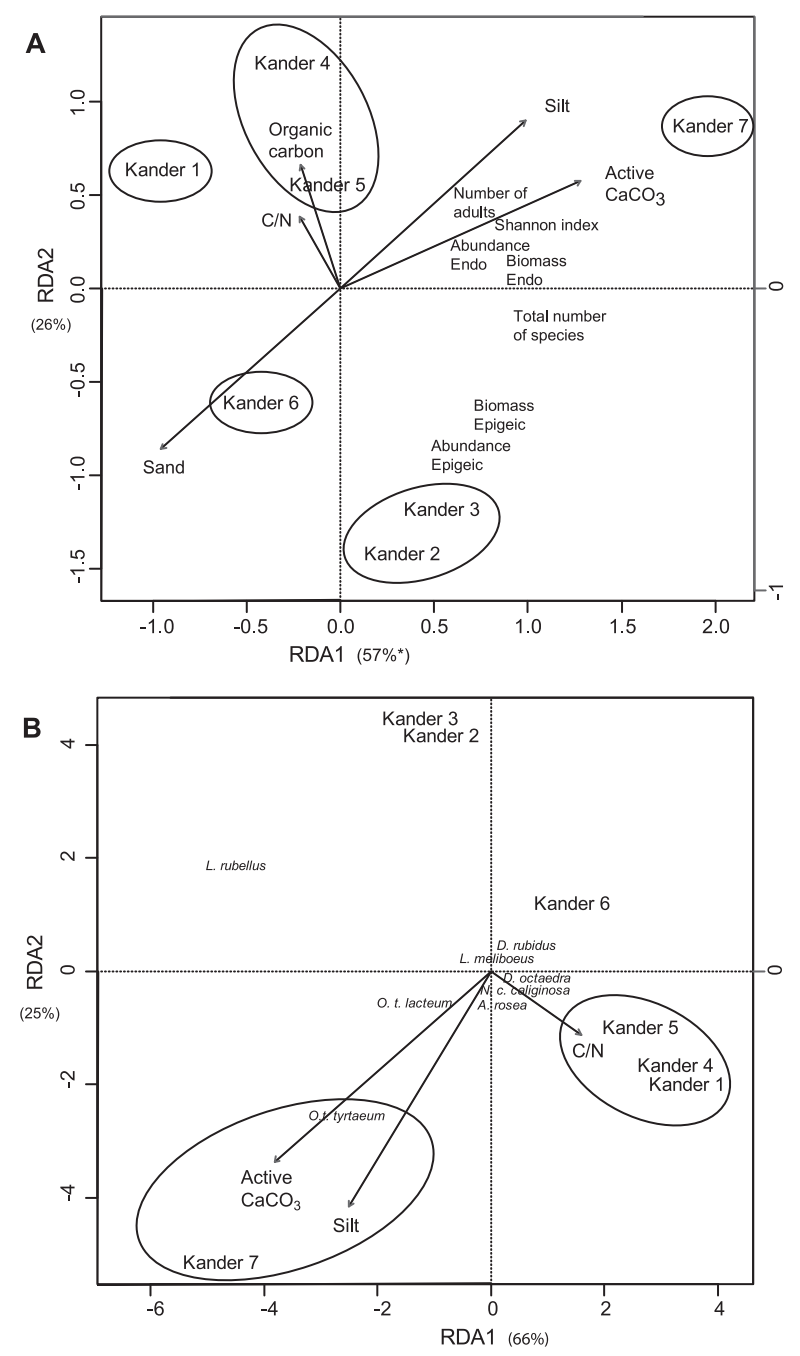

Fig. 4. RDA analysis (A) and forward selection of explanatory variables (B). The sampling plots were projected according to their soil parameters and their species biomass. See Table 3 for earthworm species.

very brief and earthworm abundance is certainly determined by other biological properties (stress resistance, dispersal power), and ecological interactions such as competition [43]. Epigeics such as L. rubellus are most vulnerable to desiccation and predation, and produce high numbers of cocoons each year (65-106). Endogeics such as Allolobophora chlorotica, A. caliginosa and A. rosea produce $8-27$ cocoons per year, and anecics such as $A$. longa produce the lowest numbers of cocoons (3-8 per year [44]).

According to Fründ et al. [43], soil quality, provision of food, and climate are the main factors that determine the abundance of earthworms in the field. Soil quality is determining the physical (texture, depth, coherence) and chemical ( $\mathrm{pH}$, oxygen supply) habitat quality in relation to species-specific preference and tolerance. In our study, we demonstrated that biomass of epigeics, representing the majority of total biomass, are correlated to the topsoil quality, i.e. the textural factors, active carbonates and organic matter quality.

Another factor to consider is the provision of food (mainly organic matter), which determines the carrying capacity/maximum population size and may be various in quantity and quality. As in situ litter fall is quite limited in such sparse alder and low productive forests, its amount and quality can be considered as identical among the seven plots. Therefore, the main variations of organic matter among the different topsoils are due to the inherited organic materials depending on flood events that may vary in quantity, and can be composed of different materials, such as logs, leaves accumulation or humus eroded upstream. Thus its quality, revealed by $\mathrm{C} / \mathrm{N}$ ratio and correlated with epigeics, and quantity, due to a low transformation rate, could determine earthworm populations. According to Paoletti [44] native soils with organic matter of mull and moder types generally present higher earthworm diversity and biomass. Fresh deciduous forest litter is generally attractive for earthworms only after some weathering and degradation by fungi and bacteria. The necessity for some initial breakdown of deciduous plant litter reflects that earthworms are not well equipped to digest lignin and other products derived from cellulose [44].

About climate, we can consider that mesoclimate is similar along the studied stretch but some extreme events, such as floods and droughts, can differently influence earthworm communities. Indeed, Fründ et al. [43] mentioned that catastrophic breakdowns of earthworm abundance may be observed after exceptional droughts or freezing.

The absence of anecic earthworms within the entire river site could be considered as a bioindication feature at the subalpine level, but further investigations are needed to investigate the relative importance of different kinds of stress (floods, temperature variations, competition). By contrast, and for epigeic and endogeic categories, results show a high variability of earthworm communities in term of biomass, abundance, species composition, diversity and relative importance of both categories. This high variability is one of the "pre-requisite" conditions to consider earthworms as efficient bioindicators of habitat quality at the subalpine level. These differences are not due to the mesoclimate, soil types, nor to local litter inputs, but are mainly related to the topsoil properties that are determined by inherited organic and mineral materials brought by recent flood events. These external inputs of organic and mineral components play a major role on earthworm communities, particularly on the epigeics biomass. At the species level, we observed that biomass and abundance of $L$. rubellus is generally well explained by soil parameters, such as $\mathrm{C} / \mathrm{N}$ ratio. In this way, epigeics communities and species may be particularly sensitive to variations of topsoil composition, and thus being bioindicators of the more recently inherited organic and mineral deposits due to the last flood. Consequently, we may assume that epigeics may be considered as bioindicators of the fluvial dynamics.

\section{Conclusion}

Floodplains present a complex mosaic of topsoil composition leading to a high heterogeneity of potential habitats for earthworms. The presence of some species is quite difficult to interpret because of scarce studies on this little known environment. In addition, earthworm communities depend on multiple interactions of parameters, such as stress, competition between species and/or ecological categories, time of colonisation, fluvial dynamics and especially material inheritance. Nevertheless, earthworm community changes are related to habitat quality (organic and mineral contents mainly) in a relatively small riparian area with a high flood pressure, and epigeics are good bioindicators of the fluvial dynamics in a nearnatural subalpine carbonate-rich environment. This study may be a first step to define a reference state in bioindication for natural and undisturbed sites, at subalpine level, in the framework of restoration projects or other environmental impacts. This specific site is therefore representative of calcareous rich subalpine floodplains subjected to fluvial dynamics creating very young soils where frequent erosion and sedimentation disturbances occur and when flood duration is short. However, other studies realized in comparable floodplains and 
conditions of sampling are needed to really allow the use of earthworm communities as bioindicators of habitats quality and further investigations are needed, mainly about soil parameters, floods and hydromorphic features, to complete the description of such subalpine floodplains.

\section{Acknowledgements}

The authors gratefully thank Dr Aurélie Thébault for statistical advice and Dr Charlotte Vandenberghe for revision of the English language. This research was supported by subside $\mathrm{n}^{\circ}$ PMPDP2_123031 from MHV program of the Swiss National Science Foundation and grant $\mathrm{N}^{\circ} 3100 \mathrm{A0}-116825$ (FLOOD STRUBIO project) from the Swiss National Science Foundation.

\section{References}

[1] J.A. Kushlan, Colonial waterbirds as bioindicators of environmental change, Colon, Waterbirds 16 (1993) 223-251.

[2] B.A. Markert, A.M. Breure, H.G. Zechmeister, Definitions, strategies and principles for bioindication/biomonitoring of the environment. in: B.A. Markert A.M. Breure, H.G. Zechmeister (Eds.), Bioindicators and Biomonitors: Principles, Concepts and Applications. Elsevier, Amsterdam, 2003, pp. 3-40.

[3] N.M. van Straalen, Evaluation of bioindicator systems derived from soil arthropod communities, Applied Soil Ecology 9 (1998) 429-437.

[4] N.M. van Straalen, D.A. Krivolutsky, Bioindicator Systems for Soil Pollution. Kluwer Academic Publishers, Dordrecht, 1996.

[5] P. Andres, E. Mateos, Soil mesofaunal responses to post-mining restoration treatments, Applied Soil Ecology 33 (2006) 67-78.

[6] A. Ruf, A maturity index for predatory soil mites (Mesostigmata: Gamasina) as an indicator of environmental impacts of pollution on forest soils, Applied Soil Ecology 9 (1998) 447-452.

[7] W. Didden, Oligochaeta. in: B.A. Markert, A.M. Breure, H.G. Zechmeister (Eds.) Bioindicators and Biomonitors: Principles, Concepts and Applications. Elsevier, Amsterdam, 2003, pp. 555-576.

[8] C. Klok, J. Thissen, Are laboratory derived toxicity results informative for field situations? Case study on earthworm populations contaminated with heavy metals, Soil Biology and Biochemistry 41 (2009) 251-255.

[9] A.J. Schouten, A.M. Breure, J. Bloem, W. Didden, P.C. de Ruiter, H. Siepel, Life Support Functions of the Soil: Operationalization for the Policy. National Institute of Public Health and the Environment, Bilthoven, 1999.

[10] P.D.T. Lavelle, M. Aubert, S. Barot, M. Blouin, F. Bureau, P. Margerie, P. Mora, Soil invertebrates and ecosystem services, European Journal of Soil Biology 42 (2006) 3-15.

[11] P. Lavelle, D. Bignell, M. Lepage, V. Wolters, P. Roger, P. Ineson, O.W. Heal, S. Dhillion, Soil function in a changing world: the role of invertebrate ecosystem engineers, European Journal of Soil Biology 33 (1997) 159-193.

[12] P. Jouquet, J. Dauber, J. Lagerlof, P. Lavelle, M. Lepage, Soil invertebrates as ecosystem engineers: intended and accidental effects on soil and feedback loops, Applied Soil Ecology 32 (2006) 153-164.

[13] C.A. Edwards, P.J. Bohlen, Biology and Ecology of Earthworms. Chapman \& Hall, London, 1996.

[14] K.E. Lee, Earthworms: Their Ecology and Relationships with Soil and Land Use Academic Press, Australia, 1985.

[15] P. Lavelle, Earthworm activities and the soil system, Biology and Fertility of Soils 6 (1988) 237-251.

[16] S. Ammer, K. Weber, C. Abs, C. Ammer, J. Prietzel, Factors influencing the distribution and abundance of earthworm communities in pure and converted Scots pine stands, Applied Soil Ecology 33 (2006) 10-21.

[17] E. Lapied, J. Nahmani, G.X. Rousseau, Influence of texture and amendments on soil properties and earthworm communities, Applied Soil Ecology 43 (2009) $241-249$.

[18] M. Ausden, W.J. Sutherland, R. James, The effects of flooding lowland wet grassland on soil macroinvertebrate prey of breeding wading birds, Journal of Applied Ecology 38 (2001) 320-338.
[19] M.I. Zorn, C.A.M. Van Gestel, H. Eijsackers, Species-specific earthworm population responses in relation to flooding dynamics in a Dutch floodplain soil, Pedobiologia 49 (2005) 189-198.

[20] M. Ivask, J. Truu, A. Kuu, M. Truu, A. Leito, Earthworm communities of flooded grasslands in Matsalu, Estonia, European Journal of Soil Biology 43 (2007) 71-76.

[21] C. Guenat, F. Bureau, G. Weber, F. Toutain, Initial stages of soil formation in a riparian zone: importance of biological agents and lithogenic inheritance in the development of the soil structure, European Journal of Soil Biology 35 (1999) 153-161.

[22] G. Bullinger-Weber, R.C. Le Bayon, C. Guenat, J.M. Gobat, Influence of some physicochemical and biological parameters on soil structure formation in alluvial soils, European Journal of Soil Biology 43 (2007) 57-70.

[23] C. Salomé, C. Guenat, G. Bullinger-Weber, J.-M. Gobat, R.C. Le Bayon. Changes in earthworm communities in alluvial forests. Importance of Fluvial Dynamics, Unpublished results.

[24] M.A. Palmer, E.S. Bernhardt, J.D. Allan, P.S. Lake, G. Alexander, S. Brooks, J. Carr, S. Clayton, C.N. Dahm, J.F. Shah, D.L. Galat, S.G. Loss, P. Goodwin, D.D. Hart, B. Hassett, R. Jenkinson, G.M. Kondolf, R. Lave, J.L. Meyer, T.K. O'Donnell, L. Pagano, E. Sudduth, Standards for ecologically successful river restoration, Journal of Applied Ecology 42 (2005) 208-217.

[25] M.A. Palmer, E.S. Bernhardt, Hydroecology and river restoration: ripe for research and synthesis, Water Resources Research 42 (2006) W03S07.

[26] C.M. Lorenz, Bioindicators for ecosystem management, with special reference to freshwater systems. in: B.A. Markert, A.M. Breure, H.G. Zechmeister (Eds.), Bioindicators and Biomonitors: Principles, Concepts and Applications. Elsevier, Amsterdam, 2003, pp. 123-152.

[27] S. Woolsey, F. Capelli, T. Gonser, E. Hoehn, M. Hostmann, B. Junker, A. Paetzold, C. Roulier, S. Schweizer, S.D. Tiegs, K. Tockner, C. Weber, A. Peter, A strategy to assess river restoration success, Freshwater Biology 52 (2007) 752-769.

[28] N.M. Plum, J. Filser, Floods and drought: response of earthworms and potworms (Oligochaeta: Lumbricidae, Enchytraeidae) to hydrological extremes in wet grassland, Pedobiologia 49 (2005) 443-453.

[29] IUSS Working Group WRB, World Reference Base for Soil Resources 2006. FAO, Rome, 2006.

[30] J.-D. Gallandat, J.-M. Gobat, C. Roulier, Cartographie des zones alluviales d'importance nationale, in: Office fédéral de l'environnement, des forêts et du paysage. Berne, 1993, p. 112 + annexes.

[31] A.P. Lawrence, M.A. Bowers, A test of the 'hot' mustard extraction method of sampling earthworms, Soil Biology \& Biochemistry 34 (2002) 549-552.

[32] M.B. Bouché, Lombriciens de France: écologie et systématique. Institut national de la Recherche Agronomique, Paris, 1972.

[33] R.W. Sims, B.M. Gerard, Earthworms: note for the identification of British species, Field Studies Council, Shrewsbury, 1999.

[34] M.B. Bouché, Strategies lombriciennes, Ecological Bulletins (1977) 122-132.

[35] M.R. Carter, E.G. Gregorich, Soil Sampling and Methods of Analysis. CRC Press, Boca Raton, 2007.

[36] The R Foundation for Statistical Computing, Version 2.10 .0 (2009).

[37] F.G. Blanchet, P. Legendre, D. Borcard, Forward selection of explanatory variables, Ecology 89 (2008) 2623-2632.

[38] A. Cierjacks, B. Kleinschmit, M. Babinsky, F. Kleinschroth, A. Markert M. Menzel, U. Ziechmann, T. Schiller, M. Graf, F. Lang, Carbon stocks of soil and vegetation on Danubian floodplains, Journal of Plant Nutrition and Soil Science 173 (2010) 644-653.

[39] A. Cabezas, F.A. Comin, Carbon and nitrogen accretion in the topsoil of the Middle Ebro River Floodplains (NE Spain): implications for their ecological restoration, Ecological Engineering 36 (2010) 640-652.

[40] G.H. Baker, V.J. Barrett, R. Greygardner, J.C. Buckerfield, The life-history and abundance of the introduced earthworms Aporrectodea-trapezoides and A caliginosa (Annelida, Lumbricidae) in pasture soils in the Mount Lofty Ranges, South Australia, Australian Journal of Ecology 17 (1992) 177-188.

[41] P.F. Brussard, Metapopulation biology. in: I. Hanski, M.R. Gilpin (Eds.), Ecology, Genetics, and Evolution, Science, vol. 277, 1997, pp. 527-528.

[42] P. Margerie, T. Decaëns, F. Bureau, D. Alard, Spatial distribution of earthworm species assemblages in a chalky slope of the Seine Valley (Normandy, France), European Journal of Soil Biology 37 (2001) 291-296.

[43] H.-C. Fründ, U. Graefe, S. Tischer, Earthworms as bioindicators of soil quality. in: A. Karaca (Ed.), Biology of Earthworms. Springer-Verlag, Berlin, 2011, pp. 261-278.

[44] M.G. Paoletti, The role of earthworms for assessment of sustainability and as bioindicators, Agriculture Ecosystems \& Environment 74 (1999) 137-155.

[45] G.E. Petts, C. Amoros, Fluvial Hydrosystems. Chapman \& Hall, London, 1996. 